\title{
OPTIMISATION OF THE ENVIRONMENTAL AND FINANCIAL COST OF TWO DWELLINGS IN BELGIUM
}

\author{
K. ALLACKER, F. DE TROYER \\ Department of Architecture, Urbanism and Planning, \\ Faculty of Engineering, Katholieke Universiteit Leuven, Belgium.
}

\begin{abstract}
A four-year project ( $\mathrm{SuFiQuaD}$ ) has started in 2007 to optimise the sustainability of the Belgian dwelling stock, focussing on the environmental impact, the financial cost and the qualities. The whole life cycle of representative housing types is assessed and recommendations for improvement are formulated. The environmental impact is evaluated through a life cycle assessment and is expressed in monetary terms, while a life cycle cost analysis is executed for the financial evaluation. A multi-criteria analysis is used for the quality evaluation considering aspects as for example size of rooms, available wall length for furniture and acoustical performance. For the optimisation the Pareto principle is used, searching for the highest life cycle cost reduction for the smallest investment increase and for the highest quality increase for the lowest life cycle cost increase. This paper elaborates on the developed methodology and the results of the implementation to two dwellings (results of the first phase of the research).

The analysis reveals that it is feasible to obtain a large reduction in the life cycle environmental cost for only a minor extra financial investment and life cycle cost. Furthermore, financial-based decisions prove to differ from environmental-based ones. For the case studies, internalisation of the environmental cost leads to an average increase in investment cost of $8 \%$; while the maintenance cost (including cleaning and replacements) increases by $2 \%$ and the heating cost by $55 \%$. The life cycle environmental cost is mainly determined by the heating cost, while the financial cost is above all determined by the investment and maintenance costs. Although the environmental and financial cost, or one of both, is higher for a certain option, one may choose for it because of its better quality. This is clearly shown by the inclusion of the quality aspects in the optimisation procedure.
\end{abstract}

Keywords: life cycle assessment, life cycle costing, monetary valuation, multi-criteria analysis, optimisation, Pareto, quality assessment.

\section{INTRODUCTION}

In Belgium, as in other countries, the construction sector is responsible for a high environmental impact. Residential buildings are the focus of the research since these represent the largest share of the building stock (82\%) [1]. The houses are moreover poorly insulated (details are reported in the survey on the insulation thickness of the building envelop of new residential buildings in the European countries [2]) and hardly any attention is paid to the environmental impact of the applied building materials. Furthermore, a lot of transportation is generated and the amount of building waste is enormous. Although people are more conscious than a decade ago and the government has undertaken some important measures [3, 4], no overall change is noticeable.

Current approaches in Belgium aiming at a sustainable development of the building sector focus on different aspects separately (amongst others material suppliers and energy use of end users), but do not consider the complex interrelations (e.g. use of building materials with a higher initial environmental impact which lead to a lower life cycle impact due to a reduced energy demand of the building). This allows for a detailed analysis but misses a global objective by losing the overall picture. Comprehensive strategies are lacking. The research described in this paper contributes to the search for these strategies. This text is a further elaboration of the methodology that was summarised in the paper 'Striving for a more sustainable Belgian dwelling stock' and was presented on the conference 'The Sustainable City 2008' in September 2008 [5]. 


\section{OBJECTIVES}

The main objective of the research was to identify actions in order of priority to move towards a more sustainable residential sector in Belgium. Priorities were sought to inform both the private decision maker and the government. The former is primarily interested in actions that lead to both an environmental and financial benefit. The task of the government may lie in stimulating measures that lead to an environmental benefit, but require high financial investment or life cycle costs.

This paper focuses on the developed methodology, illustrated by the analysis of two dwellings. The analysis investigated the consequences of the choice for a certain dwelling type, spatial characteristics and technical solutions on the financial cost and environmental impact. More particularly, possible conflicts between decisions based on financial investment and life cycle costs and life cycle environmental impact were identified. Finally, the quality of the dwellings (e.g. size of rooms, available wall length for furniture and acoustical performance) was assessed to investigate the relation between quality and costs/impacts.

\section{INTEGRATED SUSTAINABILITY ASSESSMENT}

Ever since the concept of sustainable development has been debated worldwide and despite the consensus on its importance, there is no agreement on a more detailed elaboration of the general definition. However, since the 1990s it is broadly acknowledged that three dimensions are incorporated within the concept, namely the economic, environmental and social aspect [6-8]. Sometimes a fourth dimension, the cultural dimension, is added. Despite the importance of all dimensions, the assessment method in this research focused on the environmental and economic aspect. The social aspects, however, were considered when implementing the proposed methodology and implementation results in policy regulations.

During the design of a dwelling, the goal is often a minimum investment cost for a set of minimum performances. However, integrated life cycle design could enhance the overall performance and optimise the life cycle cost and environmental impact of the dwelling. As stated by Oberg [9], 'integrated lifetime engineering is an approach to bridge the gap between the short term design perspective and the long life nature and complexity of a building'.

The developed assessment method was, therefore, based on an integrated approach and consists of a combination of existing techniques: traditional financial evaluation approaches, environmental assessment methods and multi-criteria analysis (MCA) for the quality evaluation. In the following paragraphs, the different aspects of the approach are described. In the second part of the paper, the analysis of two dwellings is elaborated.

\subsection{Environmental impact}

\subsubsection{Life cycle assessment - concept}

According to the ISO 14040 standard [10], life cycle assessment (LCA) is defined as 'the compilation and evaluation of the inputs, outputs and potential environmental impacts of a product system throughout its life cycle'. It is a well-established technique and has a broad international acceptance [11-18]. It was, therefore, selected within this research for the assessment of the potential environmental impact of the dwellings. In the subsequent paragraphs the procedure is briefly elaborated, followed by a description of its application at the building level and the methodological choices within this research.

\subsubsection{General procedure and building-specific aspects}

\subsubsection{General procedure}

According to ISO 14040 [19], an LCA must be performed in four iterative steps: (1) goal and scope definition; (2) life cycle inventory (LCI); (3) life cycle impact assessment (LCIA) and (4) interpretation of the results. 
LCI involves the collection of the data and definition of procedures to quantify the in- and outputs of the studied product (e.g. building) for all stages of the life cycle. Input data cover all natural resources, while the output data include products, co-products, waste, emissions to air, discharges to water and soil and other environmental exchanges (e.g. losses of heat). The product of interest in this research was the dwelling.

LCIA provides additional information to improve the environmental significance of a product's (dwelling) LCI results. In the LCIA, the results of the LCI are linked to specific environmental impact categories. $\mathrm{CO}_{2}$ emissions (inventory) are for example linked to global warming (impact). First of all the environmental effects to be considered need to be determined, second one needs to define which loads lead to which effects (classification) and to which extent (characterisation). Two additional steps can be added: normalisation and weighting. Normalisation is needed to evaluate the importance of the results: during normalisation the calculated environmental effects are compared with a reference value. Most often this reference value is the average yearly environmental effect caused by an European citizen. Weighting is required if a single score is desired.

The LCA procedure as defined by ISO 14040 was followed for the assessment of the environmental impact. However, a single score was calculated within the optimisation procedure despite the prohibition of ISO 14040/44 [10, 20] to calculate one single environmental indicator within a comparative LCA study disclosed to the public. This was desirable in order to make straightforward decisions when decisions on specific environmental impacts are contradictory. Since it did not concern a comparison of two specific materials, but of alternative complex combinations of many materials and processes, the comparison of a single score seemed justified. Moreover, no information was lost on the importance of the different life phases, processes and effects and the single score was analysed in detail for the cases of interest. This methodological choice, however, implies that the assessment is not in accordance with the ISO guidelines.

\subsubsection{Building-specific aspects}

Because of its complexity and typically relatively long life span, applying LCA to a building is more than the addition of building materials and has become a distinct working area within LCA practice. The following characteristics contribute to the need for a different approach [16, 20]:

- Highly multi-functional character;

- Extremely long (and unknown) life expectancy;

- Site specificity and local character of many of the impacts;

- Many environmental impacts and changes during its use phase;

- Unknown behaviour of the inhabitants;

- Heterogeneous composition;

- Close integration with the surrounding built environment, particularly urban infrastructure (e.g. roads, supply/sewerage lines and green space).

For a detailed elaboration on each of these aspects, the International Energy Agency (IEA) and Society of Environmental Toxicology and Chemistry (SETAC) report can be consulted. In the subsequent paragraphs, the most important decisions within the developed methodology are summarised.

\subsubsection{Highly multi-functional character}

Products can only be compared if these fulfil an identical function. Buildings, however, have a highly multi-functional character and it is in practice impossible to consider buildings with identical performance. Commonly, the environmental impact of buildings is calculated per $\mathrm{m}^{2}$ floor over a typical year $[15,21]$. The performance of this $\mathrm{m}^{2}$ most probably differs for the different buildings 
considered. A second drawback of this functional unit is that larger buildings often lead to a lower impact per $\mathrm{m}^{2}$ floor (since one divides by a larger number). It would, however, be wrong to conclude that larger dwellings induce a lower impact than smaller dwellings.

In this research, the impact was expressed per $\mathrm{m}^{2}$ floor, assuming an identical life span for all analysed dwellings. The costs were furthermore expressed per dwelling and per inhabitant to investigate the influence of the choice of functional unit on the results. The last reference base (per inhabitant) is, however, less robust than the other references since the number of inhabitants may change during the life span of the dwelling. A quality evaluation was included to assess the diverging performance of the compared dwellings.

\subsubsection{Life expectancy}

The life expectancy of a building can be determined by its technological, functional or economic life span. The life span is a decisive parameter but hard to predict. Within the ISO 15686/1 document [22] concerning service life planning of buildings and constructed assets, a distinction is made between the estimated (ESL) and reference service life (RSL). The RSL needs to be used in comparative analysis. SETAC mentions RSLs for different countries, varying from 60 to 100 years [18]. For the Belgian context no RSL is mentioned. Ammar and Longuet [23], however, mention an average service life of 60 years for dwellings in the Belgian context, which was considered acceptable for this research.

During this relatively long life span, parts of the building are replaced when their service life is shorter than the service life of the dwelling. These replacements were considered and comprised both the replacement of whole parts (such as non-bearing inner walls) as materials (e.g. paint on walls). A minimum quality over the whole life cycle of the material or building part was assumed and their service life was estimated based on an extended literature study (amongst others [24-27]).

In LCA practice, two methods can generally be distinguished for replacements: pro-rating or not. Pro-rating means that the calculated number is not changed (e.g. a window with a life span of 30 years will be replaced 1.66 times in a building with a life span of 50 years). No pro-rating means the product would be replaced once (after 30 years). As described in SETAC [20], an argument against pro-rating is that it does not reflect the true activities. An argument in favour of pro-rating is that it reflects average situations. In this research the option of no pro-rating was chosen.

For the replacements at the end of the life span of the dwelling, a distinction was made between necessary replacements and replacements which are only needed for comfort or aesthetics. The former ones were executed until the end of the life span of the dwelling, while the latter depended on the life span of the subparts to be replaced. When the remaining life span of the dwelling was shorter than half of the life span of the subpart to be replaced, the latter was not replaced anymore.

\subsubsection{Use phase and behaviour of the inhabitants}

The environmental impact of dwellings during the use phase is mainly caused by the energy use, of which heating represents the most important part in the Belgian context. Since the energy demand of lighting and electric appliances was negligible compared with the heating demand (both for existing dwellings and newly built according to current practice), these were no priorities and were thus not investigated. Moreover, the use of appliances is hardly influenced by the design of the dwelling and thus of less importance within this research. The heating demand was predicted based on steadystate simulations as is common in building LCA tools (e.g. GreenCalc [28], BREEAM [29], LEGEP [30]). Although dynamic energy simulations are more precise and should be used for a detailed energy study of a building, the steady state simulations are accurate enough for the aim of this study [31]. The Flemish Energy Performance standard, translated into a software tool by the government, was used for the calculations $[32,33]$. 
In addition to heating, the effects and periodic costs for cleaning, maintenance and replacements were also considered. The necessary processes and their frequencies were based on literature, amongst others $[34,35]$.

\subsubsection{Heterogeneous composition}

A building is composed of many different building materials and, therefore, requires a detailed bill of quantity. In order to allow a thorough inventory, the element method for cost control was used $[36,37]$. This method hierarchically divides the building into independent building elements, which are building parts the designer is accustomed to working with. Examples are foundations, floor on grade and outer walls. Within this research, the element method was extended to include life cycle cost and environmental impact estimations.

\subsubsection{Implementation within this research}

\subsubsection{Data and LCI analysis}

The data were mainly gathered from existing databases, statistics and literature. The Ecoinvent database [38] was the most important source for the inventory data. Several adaptations of the Ecoinvent records were, however, made within an iterative implementation process (e.g. imported materials and recycling processes).

The material production phase includes the cradle-to-gate data of all building materials occurring in the building. The in- and outputs per unit of material were taken from the Ecoinvent database, while the functional and physical characteristics were found in technical documentation (e.g. national technical approvals for construction materials, products and systems (ATG/BUtgb), technical reports of the Belgian Building Research Institute (BBRI) and technical data sheets of building materials).

Transportation phase 1 considers the transportation of building materials to the construction site. A literature study revealed that data specific for the Belgian context were lacking. Therefore, a limited inquiry was conducted by the BBRI. In this inquiry (to date not yet published), contractors, producers and dealers of construction products were questioned about the transportation distance, means and load percentage for different predefined categories of building materials. The Ecoinvent database was consulted for the in- and outputs per vehicle type.

As in most LCAs of buildings, the construction phase was excluded in this research since data are lacking [17].

Two processes were assessed within the use phase: cleaning, maintenance and replacements on the one hand and space heating (including the production of domestic hot water) on the other hand. As mentioned before, the energy load was calculated with the Flemish Energy Performance Legislation for Buildings (EPB) software and a high performance central heating system on natural gas was assumed. The cleaning, maintenance and replacement scenarios were based on a literature study. Ecoinvent database was used for the in- and outputs of the occurring products and processes.

The environmental impact caused by the demolition of the building is mainly due to energy use. The amount of materials to be demolished was calculated and the in- and outputs for the demolishing process were taken from Ecoinvent database.

Within the second transportation phase the transport from the building site to a disposal, incineration, re-use or recycling centre was addressed. The data were based on a limited inquiry conducted by the BBRI (to date not yet published) in analogy with the first transportation phase.

Ecoinvent database was consulted to retrieve the inventory data of the necessary processes for the waste treatment, recycling and re-use of the building materials. However, after a first implementation it became clear that the generic records available within Ecoinvent database led to unrealistic 
results. Therefore, material-specific data records were defined based on the available generic records. The end-of-life (EOL) scenarios were based on a limited inquiry conducted by the BBRI (to date not yet published).

For the EOL treatment, allocation rules were needed. Allocation stands for the partitioning of environmental impacts between systems. Different allocation methods are possible and vary from cut-off of waste and recycling processes to a full assessment. In this research, both the environmental impacts and benefits related to the EOL treatment were allocated to the analysed building.

\subsubsection{Life cycle impact assessment}

According to the IEA [15], the environmental assessment of buildings commonly considers four environmental effects: global warming potential (GWP), acidification potential (AP), ozone depletion potential (ODP) and nutrification potential (NP). The widely used impact assessment method Eco-Indicator 99 [39] considers amongst others the above-mentioned effects, but expresses these in three main damage categories: damage to human health, quality of ecosystems and depletion of resources. The damage to human health consists of sub-aspects such as global warming, carcinogens, ozone depletion, respiratory effects and irradiation. The effects on the quality of ecosystem are determined by ecotoxicity, acidification/eutrophication and land use/conversion. The depletion of resources consists of both the depletion of minerals and fossil fuels.

A detailed analysis of frequently used building materials revealed that it is important to include as many effects as possible. The developed methodology, therefore, assessed all effects as defined within Eco-Indicator 99. The environmental impact was furthermore expressed in monetary values (EURO). This enables the evaluation of the environmental impact and financial cost simultaneously. Moreover, the value of money is known by all decision makers and was, therefore, assumed to improve communication and consequently to facilitate action.

The translation of the environmental impacts into monetary values was based on a combination of existing methods. For the environmental effects of the greenhouse gas emissions, the monetary value was based on the combined information from Tol [40], Stern [41] and Watkiss et al. [42], and equals $50 € /$ ton $\mathrm{CO}_{2}$ equivalent. The monetary values of other airborne emissions $\left(\mathrm{PM}_{2.5}, \mathrm{NH}_{3}, \mathrm{SO}_{2}, \mathrm{NO}_{\mathrm{x}}\right.$, VOCs) were based on the ExternE studies, more specifically the values of the CAFE (Clean Air For Europe) project for the Belgian context were used [43]. The values are summarised in Table 1.

A monetary value was determined for the 'disability adjusted life years' (DALYs) caused by the emissions and/or effects not included within ExternE. The value of 60,000 €/DALY was assumed based on several sources [44]. Acidification, eutrophication, ecotoxic emissions and land use were included by translating the potentially disappeared fraction (PDF) of species $\times \mathrm{m}^{2} \times$ year, as assessed within Eco-Indicator 99, into monetary values based on the studies mentioned before. The value of

Table 1: Monetary values of the key airborne emissions according to CAFE for the Belgian context (low end scenario) [43].

\begin{tabular}{ccc}
\hline Airborne emissions & External cost & Unit \\
\hline $\mathrm{PM}_{2.5}$ & 61,000 & $€ /$ ton \\
$\mathrm{SO}_{2}$ & 11,000 & $€ /$ ton \\
$\mathrm{NO}_{\mathrm{x}}$ & 5,200 & $€ /$ ton \\
$\mathrm{NH}_{3}$ & 30,000 & $€ /$ ton \\
$\mathrm{VOC}$ & 2,500 & $€ /$ ton \\
\hline
\end{tabular}


$0.49 € /\left(\mathrm{PDF} \times \mathrm{m}^{2} \times\right.$ year $)$ was retained. For the depletion of minerals and fossil fuels, the monetary value of $0.0065 € / \mathrm{MJ}$ surplus energy was determined.

The future environmental costs, which occur during the life span of the dwelling and at the end of its life span, were calculated following the same approach that was used for the financial cost. This is further elaborated in the next section.

\subsection{Financial cost}

The financial costs were evaluated at the micro-economic level, meaning that the costs for the building owner were investigated. In addition to the investment cost, the life cycle costs were also considered. The latter not only include the investment costs, but also the costs during use phase (periodic costs) and at the end of the life span of the dwelling.

The life cycle cost was calculated by the sum of the present values (SPV) of all costs. The material and labour costs were taken from the ASPEN database [45], valid for the Belgian context. In contrast to the environmental cost, the initial financial cost includes the construction costs. If data were lacking product-specific data were used. The cleaning and maintenance costs were based on literature from [46-51]. The financial cost of natural gas (for heating) was assumed to be $0.047 € / \mathrm{kWh}$ (inclusive VAT) which is mentioned as the average price for households in 2006 in Belgian statistics [52].

For the economic parameters, the following assumptions were made (real terms): discount rate equals $2 \%$, growth rate of material cost $0 \%$, growth rate of labour cost $1 \%$, growth rate of energy cost $2 \%$. These assumptions were based on an analysis of the evolution of prices during the previous 50 years in Belgium $[53,36,54]$ and on predictions of evolutions in the future $[55,56]$. For the future environmental costs, the same rates were assumed with the exception of the discount rate. A lower discount rate of $1 \%$ was used to calculate the future environmental costs since a social discount rate is assumed to be lower than a private discount rate [41, 57].

For the analysis of the case studies in this paper, the financial cost for the demolition and EOL treatment were not included since data were lacking during the first phase of the research. These were, however, further investigated during the second phase and were included in the final version of the method.

\subsection{Quality evaluation}

The quality assessment was based on an existing method, consisting of an MCA [58]. The different quality aspects were awarded a score on a scale of 10 , defined by a score function. The single endscore was calculated by the sum of the weighted scores. Within the original method, an expert panel defined the weighting factors.

Some adaptations were made to the original method. First of all, some aspects were eliminated to avoid double counting. Second, some score functions were redefined according to the new European and Belgian norms (e.g. acoustical standards). The method considers aspects such as the dimensional characteristics (e.g. size of rooms and width of rooms), the functional characteristics (e.g. relation between the rooms and flexibility), the technical characteristics (e.g. safety and acoustical performance) and finally the surroundings of the dwelling. An overview is given in Table 2 (adapted version).

\subsection{Optimisation}

Literature on multi-objective decision problems provides a detailed description of different possible optimisation procedures (amongst others: [31, 59-61]). Within this research a cost-benefit 
Table 2: Description of the main aspects and sub-aspects with their corresponding weighting factors for the adapted method.

\begin{tabular}{lccc}
\hline Global distribution of points & $\begin{array}{c}\text { Maximum points } \\
\text { sub-aspects }\end{array}$ & $\begin{array}{c}\text { Maximum points } \\
\text { main aspects }\end{array}$ & $\begin{array}{c}\text { Percentages } \\
\% \text { (max) }\end{array}$ \\
\hline Dimensional characteristics & 1050 & 2500 & $34.58 \%$ \\
Size of rooms & 650 & & \\
Room width & 500 & & \\
Windows size + orientation & 300 & 1500 & $20.75 \%$ \\
Efficient use of floor area & & & \\
Functional characteristics & 100 & & \\
Ventilation and safety & 130 & & \\
Hygrothermal characteristics & 350 & & \\
Acoustical performance & 690 & & \\
Technical installations & 300 & & \\
Surface of materials: maintenance & & & \\
Surroundings of the dwelling & 810 & & \\
Direct surroundings & 850 & & \\
Broader surrounding & & & \\
Financial cost & 0 & 7230 & $100.00 \%$ \\
Financial cost & & & \\
Total & & & \\
\hline
\end{tabular}

analysis was chosen as optimisation technique. The optimisation started from a defined reference dwelling (for each of the different dwelling types considered) and was based on comparative analysis.

The optimisation procedure consisted of two steps. In the first step only costs were considered. Starting from the option with the lowest investment cost, preference was given to the option with the highest marginal return. Or in other words, the option with the highest reduction in the life cycle cost over the additional investment was identified. In a second step, the qualities were integrated into the analysis. Starting from the option with the lowest life cycle cost, the option that offered the highest quality improvement over additional life cycle cost was selected. The subset of preferred options was identified and graphically presented by the Pareto front.

\section{IMPLEMENTATION OF THE METHODOLOGY}

The method described above was translated into an assessment tool and applied to several dwelling types. The results for two of these dwelling types, a detached house and an apartment, are elaborated in the subsequent paragraphs. The different costs during the different life phases were subdivided as follows: initial cost (from extraction of resources to the building process of the house), periodic cost (cleaning, maintenance and replacements), heating cost, demolition cost, cost for transport to the EOL treatment and finally the EOL treatment cost. Finally, a differentiation was made between environmental cost, financial cost and total cost. The latter was defined as the sum of the former two. 


\subsection{Dwelling description}

The detached house (Fig. 1) is L-shaped, consists of only a ground floor level and is therefore not compact at all. The house consists of a living room, kitchen and bathroom, storage room and three bedrooms. There is an entrance and night hall. There is no garage in the house. The garden is surrounding the house and there is a terrace adjacent to the living room [5].

The apartment (Fig. 2) is situated in the centre of an apartment building consisting of 11 identical floors, a ground floor (entrance, storage, etc.) and a technical top floor. The apartment consists of one bedroom, an entrance hall, living room, kitchen, bathroom, storage and separate toilet; and has a small balcony. Part of the apartment building consists of shared space. The constituting elements were included in the analysis by assigning a proportion of these to the analysed apartment in accordance with its floor ratio [62]. The most important characteristics of both dwellings are summarised in Table 3.
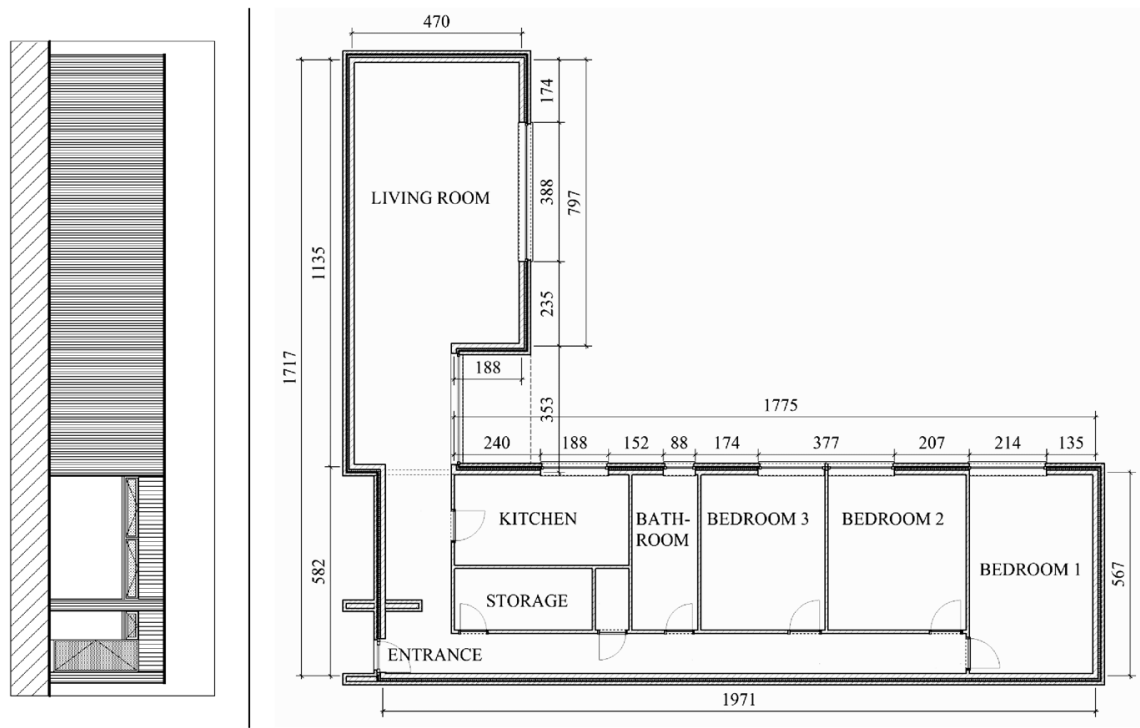

Figure 1: Floor plan and front facade of the detached house.
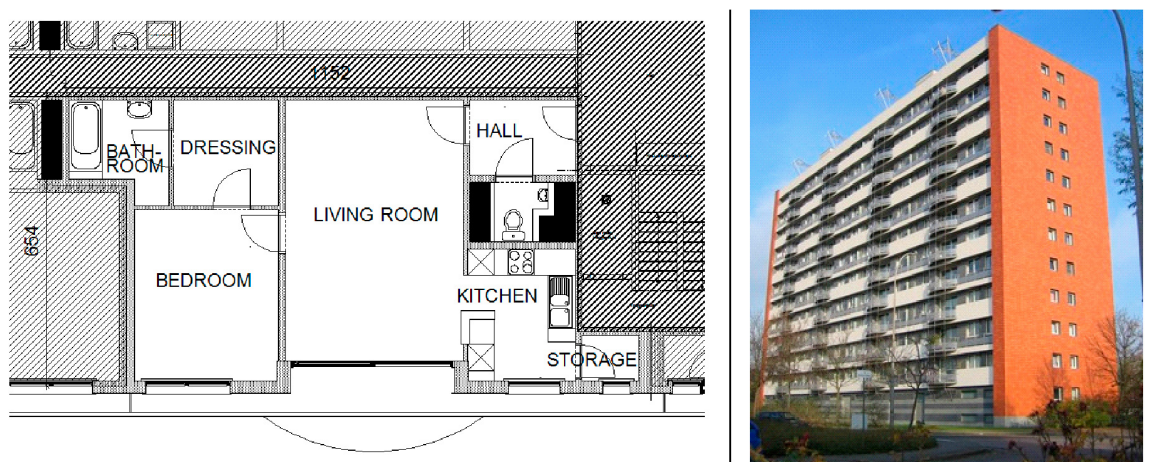

Figure 2: Floor plan of the apartment and picture of the building. 
Table 3: Characteristics of the two case studies.

\begin{tabular}{lcc}
\hline & Detached house & Apartment \\
\hline Shape & L-shaped & Rectangular \\
Floor area & $159 \mathrm{~m}^{2}$ & $69 \mathrm{~m}^{2}$ \\
Compactness (heated volume/ & $0.75 \mathrm{~m}$ & $5.12 \mathrm{~m}$ \\
Surface of thermal envelope) & & \\
Number of bedrooms & 3 & 1 \\
Number of inhabitants & 4 & 2 \\
Number of floors & 1 & 1 \\
Floor on grade & $159.00 \mathrm{~m}^{2}$ & $7.85 \mathrm{~m}^{2}$ \\
Foundation/ pile foundation & $79.18 \mathrm{~m}^{2}$ & $9.64 \mathrm{~m}^{2}$ \\
Outer wall & $174.9 \mathrm{~m}^{2}$ & $36.72 \mathrm{~m}^{2}$ \\
Loadbearing inner wall & $0 \mathrm{~m}^{2}$ & $24.87 \mathrm{~m}^{2}$ \\
Non-bearing inner wall & $105.26 \mathrm{~m}^{2}$ & $23.35 \mathrm{~m}^{2}$ \\
Separating wall & $0 \mathrm{~m}^{2}$ & $40.16 \mathrm{~m}^{2}$ \\
Floor & $0 \mathrm{~m}^{2}$ & $83.22 \mathrm{~m}^{2}$ \\
Flat roof & $159.00 \mathrm{~m}^{2}$ & $6.96 \mathrm{~m}^{2}$ \\
Flat roof edge & $78.71 \mathrm{~m}^{2}$ & $2.42 \mathrm{~m}^{2}$ \\
Windows & $35.14 \mathrm{~m}^{2}$ & $14.19 \mathrm{~m}^{2}$ \\
Interior doors & $18.83 \mathrm{~m}^{2}$ & $16.12 \mathrm{~m}^{2}$ \\
\hline
\end{tabular}

\subsection{Element description}

Different technical solutions for the elements were selected for comparative analysis. Five variants of the outer walls (OW1 - OW5) were analysed, varying in finishing and structure (Fig. 3). For the exterior finishing, a brick veneer was compared with wood cladding and cement fibre board. For the loadbearing elements, both clay building blocks and a timber frame were analysed. The interior finishing consists of gypsum board or gypsum plaster. Moreover, the first variant (OW1) was also considered without thermal insulation (OW1 - no insulation).

Two alternatives for the loadbearing inner walls of the apartment building were considered, namely clay building blocks (LIW1) and hollow concrete blocks (LIW2). Both are $14 \mathrm{~cm}$ thick and are finished with gypsum plaster at both sides.

For the non-bearing inner walls, four alternatives were compared: clay building blocks (NIW1), calcium silicate blocks (NIW2), a timber frame with a single (NIW3) and double gypsum board finishing (NIW4). The first three variants were finished with gypsum plaster at both sides.

For the flat roof a concrete slab and timber construction were considered (Fig. 4). Again the first variant was also analysed without thermal insulation (FR1 - no insulation). For all flat roofs the roof edge was kept unchanged and consists of an aluminium section. The vertical part of the roof edge which is a continuation of the outer wall - was of course changed according to the selected outer wall.

For the floor on grade two alternatives were analysed, the first one (FG1) consisted of a concrete floor slab with ceramic tiles as floor finishing, the second (FG2) was identical to the first but was insulated with $4 \mathrm{~cm}$ polyurethane (Fig. 5). 


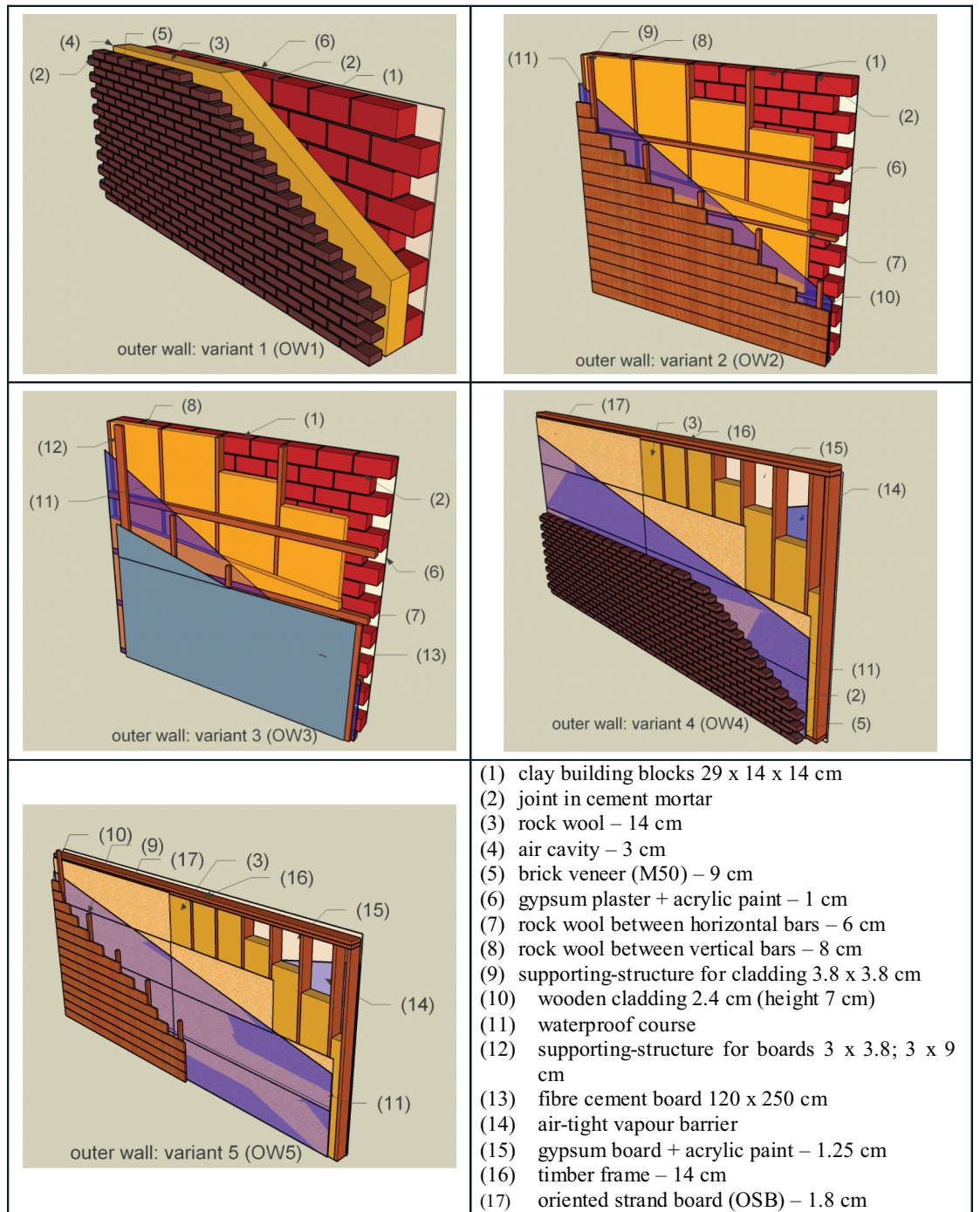

Figure 3: Outer walls: graphical representation of the analysed variants.

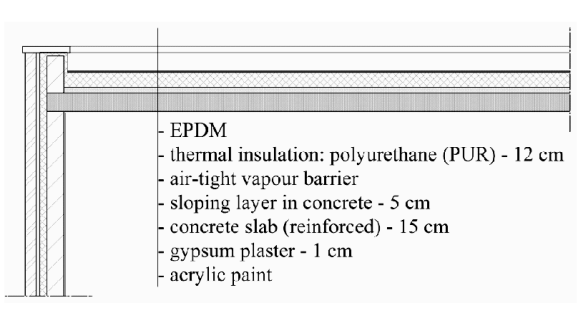

FR1

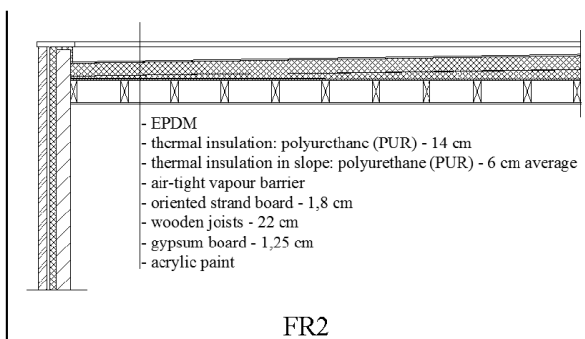

FR2

Figure 4: Flat roof: graphical representation of the analysed variants. 


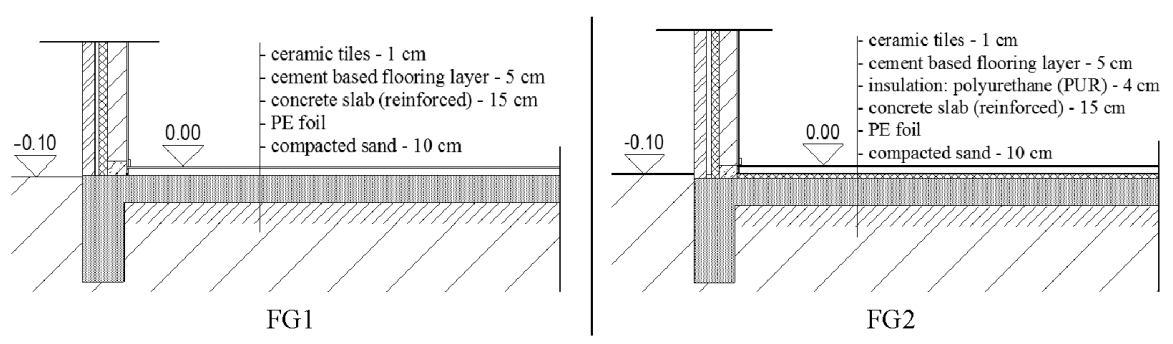

Figure 5: Floor on grade: graphical representation of the analysed variants.

The foundation of the detached house consisted of a light concrete beam of which the width varied according to the thickness of the selected outer wall and the height according to the thickness of the chosen floor on grade. For the apartment building three types of pile foundations were compared: in situ concrete (PF1), prefabricated concrete drilled (PF2) and prefabricated concrete-driven piles (PF3).

The intermediate floors of the apartment were kept unchanged and consisted of a concrete slab $(15 \mathrm{~cm})$ with gypsum plaster as ceiling finish and ceramic tiles on a cement-based screed as floor finishing. For the apartment, however, no structural parts in timber were analysed (OW4, OW5 and FR2) since these are prohibited in Belgium for fire safety reasons.

The window frames were kept unchanged and were assumed aluminium (with thermal break). The glazing, however, was altered from normal double glazing (DG) to thermally improved glazing (TIG). The U-value of the former equals $2.3 \mathrm{~W} / \mathrm{m}^{2} \mathrm{~K}$, while it equals $1.1 \mathrm{~W} / \mathrm{m}^{2} \mathrm{~K}$ for the latter.

\subsection{Cost optimisation}

4.3.1 Analysis of the dwelling costs, focusing on the influence of the element options

The initial and life cycle costs (financial and environmental) of both dwellings were determined for the different dwelling variants. In Fig. 6, the results are shown for the financial costs and in Fig. 7 for the environmental costs of the detached dwelling, assuming a life span of 60 years. Horizontally the initial cost is plotted, while vertically the life cycle cost is shown. Both are expressed per $\mathrm{m}^{2}$ floor area. All graphs in Fig. 6 are identical, but each graph emphasises one of the building elements. The same accounts for the graphs in Fig. 7. The Pareto front is only shown in the graphs in the first row.

The upper graph reveals that insulating the floor on grade results in an increase in the initial financial (Fig. 6) and environmental cost (Fig. 7), but in a decrease in the life cycle financial and environmental cost. Among the six outer walls analysed (second graph), option four (OW4) is the most desirable from a financial point of view, while options three and five (OW3 and OW5) are preferable based on environmental cost. All the studied non-bearing inner wall variants lead to an approximately identical life cycle financial and environmental cost (third graph). Insulating the flat roof proves to be an important measure, both from a financial and environmental point of view (fourth graph). Flat roof type one (FR1) is preferable from a financial point of view, while the second type (FR2) is environmentally a better choice. Thermally improved glazing results in a higher initial and life cycle financial cost, but leads to a lower life cycle environmental cost compared with standard double glazing (fifth graph).

By comparing the financial and environmental costs (Fig. 6 and Fig. 7), it is obvious that the environmental costs are much lower than the financial costs. The ratio of environmental to financial cost 


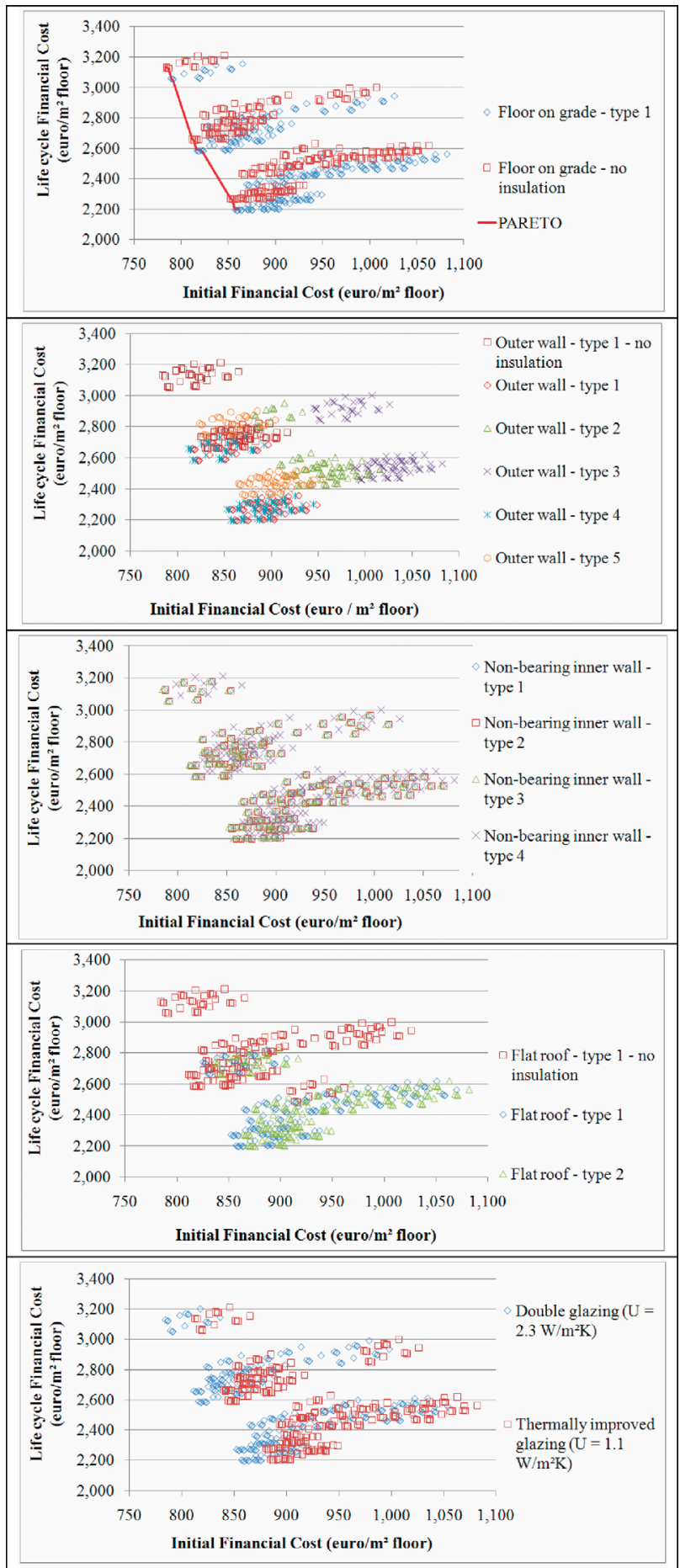

Figure 6: Detached dwelling: initial vs. life cycle financial cost, analysing the influence of the element options. 


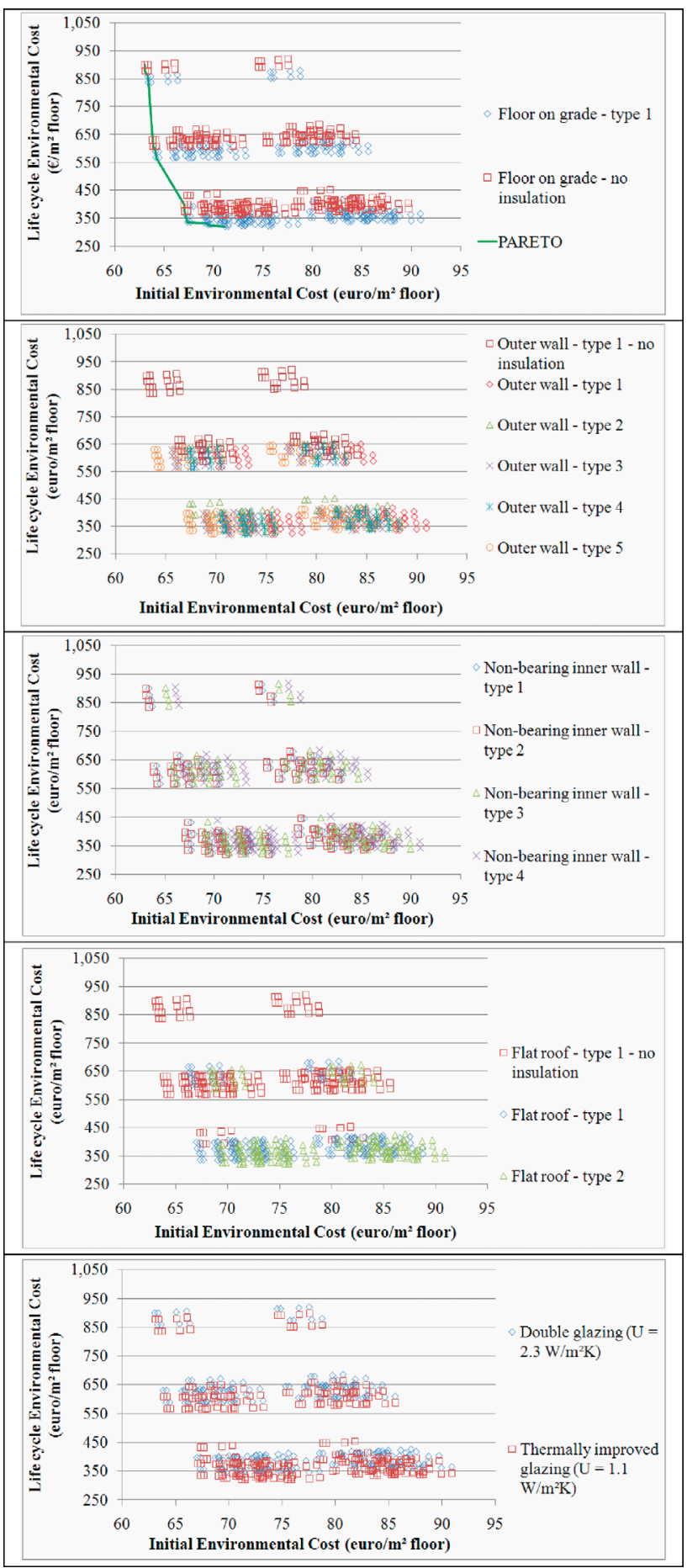

Figure 7: Detached dwelling: initial vs. life cycle environmental cost, analysing the influence of the element options. 
Table 4: Ratio of the environmental cost to the financial cost.

\begin{tabular}{lcc}
\hline & Detached house (\%) & Apartment (\%) \\
\hline Initial environmental cost/initial financial cost & 8 & 8 \\
Periodic environmental cost/periodic financial cost & 3 & 2 \\
Heating environmental cost/heating financial cost & 55 & 55 \\
Life cycle environmental cost/life cycle financial cost & 19 & 11 \\
\hline
\end{tabular}

is investigated and summarised in Table 4. The analysis reveals that internalising the environmental costs would lead to an average increase in investment cost of $8 \%$, while the periodic cost would increase by $2 \%$ on average and the heating cost by $55 \%$. For the apartment, this means an increase of $11 \%$ in the life cycle cost and for the detached house of $19 \%$.

A similar analysis was made for the apartment, leading to similar results. A comparison of the housing types revealed that both the initial and life cycle costs of the subsets of Pareto optima of the detached house were always higher than that of the apartment. However, there are options of the detached house (not the optimal ones) that result in a lower life cycle cost than some options of the apartment. This is not only true for the financial cost, but also for the environmental cost.

For the apartment, the maximum life cycle environmental cost of the Pareto subset equals 343 $€ / \mathrm{m}^{2}$ floor area, while the minimum equals $195 € / \mathrm{m}^{2}$. For this life cycle environmental cost reduction of $43 \%$, an extra environmental investment of $3.4 \%$ is required (but is thus compensated over the life span), while an extra financial investment of $42 € / \mathrm{m}^{2}$ floor area (6.4\%) is needed. It, therefore, seems feasible to significantly reduce the environmental life cycle impact for only a minor extra financial investment. Moreover, the life cycle financial cost is reduced by $9.4 \%$ and thus the extra investment is also financially viable over a life span of 60 years. For the detached house, a reduction of $64 \%$ in the life cycle environmental impact is possible. However, this requires an extra financial investment of $32 \%$. The life cycle financial cost is again reduced by $21 \%$ as a result of this environmental optimisation.

\subsubsection{Financial cost optimisation}

The subset of Pareto optima based on the financial cost consists of 16 options for the apartment and 12 options for the detached house. The option with the lowest investment cost was called the reference dwelling and proved to be, for both dwelling types, the variant which is not insulated, with inner non-bearing walls of timber frame and normal double glazing. Starting from this reference dwelling, the best investment among the different options considered is to opt for another type of inner walls, namely clay building blocks. This leads to the highest reduction in life cycle financial cost for the lowest increase in initial financial cost. However, it must be mentioned that the insulation options considered in this analysis were either no insulation or a thick insulation layer (two extremes). This explains why changing an inner wall type was preferred within a limited budget when compared with the larger investment of insulating the house [5].

If a higher investment is possible, however, one should preferably invest in insulating the floor on grade. This requires a higher investment than choosing inner walls of clay building blocks, but leads to a higher reduction in the life cycle financial cost [5].

The next optimisation steps differ between the two dwelling types. For the apartment, the next best investment is roof insulation, followed by insulating the outer walls. The final optimal solution is a completely insulated apartment with normal double glazing and inner walls of clay building 
blocks. For the detached house on the other hand, one should first opt for insulated outer walls (timber frame) and then for roof insulation. This can be explained by the large outer wall surface area of this dwelling, which when insulated results in a large reduction in the heating cost. The detached house with the lowest life cycle financial cost on the Pareto front is the dwelling with outer walls of insulated timber frame with a brick veneer, an insulated roof and floor on grade, normal double glazing and inner walls of clay building blocks.

\subsubsection{Environmental cost optimisation}

The dwelling with the lowest initial environmental cost is identical to the one with the lowest financial cost with the exception of the inner wall type which consists of calcium silicate blocks instead of timber frame. The first investment to make from an environmental viewpoint is opting for thermally improved glazing instead of normal double glazing.

For the apartment, the next measures in order of preference are insulating the floor on grade, the roof and the outer walls. The option with the lowest life cycle environmental cost is identical to the one with the lowest life cycle financial cost, but consists of inner walls of calcium silicate blocks instead of timber frame and of thermally improved glazing instead of normal double glazing.

For the detached house, the order of measures is more or less identical to those for the apartment, but the option with the lowest life cycle environmental cost on the Pareto front differs. It is a dwelling with identical inner walls (calcium silicate blocks), an identical insulated floor on grade and thermally improved glazing, but with differing outer walls (clay building blocks with an outer finishing of cement fibre board instead of a brick veneer) and a differing flat roof (consisting of a timber structure instead of a concrete slab).

\subsubsection{Total cost optimisation}

For the apartment two more options were identified on the Pareto front compared with the financial cost Pareto set. It concerns the improvement of the glazing to thermally improved glazing. In a first step this is combined with the timber framed inner walls and in a second step with inner walls of clay building blocks.

For the detached house, the Pareto front based on total cost consists of six more options than the Pareto set based on financial cost. Again, it concerns the choice for thermally improved glazing. Depending on the available budget, this is combined with other outer walls, inner walls and flat roof types. The option with the lowest life cycle total cost is the dwelling with outer walls of clay building blocks and a brick veneer with cavity insulation, a flat roof consisting of a timber structure, an insulated floor on grade, inner walls of calcium silicate blocks and thermally improved glazing. The option with the lowest life cycle cost is summarised in Table 5 for the three types of costs.

\subsubsection{Importance of the life phases}

A detailed analysis into how the different life phases contributed to the life cycle financial and environmental costs clarified the difference in Pareto subsets (Fig. 8). While the life cycle environmental cost is mainly determined by the heating cost (for the detached house $81 \%$ and for the apartment $69 \%$ ), the life cycle financial cost is more evenly distributed over the different phases. For the detached house, the initial phase is responsible for $34 \%$ on average. For the apartment this phase accounts for $32 \%$ on average. The periodic costs for cleaning, maintenance and replacements are responsible for $36 \%$ of the life cycle financial costs for the detached house as opposed to $53 \%$ for the apartment. And the heating costs are responsible for $30 \%$ and $16 \%$, respectively. 
Table 5: Description of the Pareto optima with the lowest life cycle cost for the different types of costs (financial, environmental and total) and for the two dwelling types.

\begin{tabular}{|c|c|c|c|c|c|c|}
\hline & \multicolumn{3}{|c|}{ Apartment } & \multicolumn{3}{|c|}{ Detached house } \\
\hline & $\begin{array}{c}\text { Financial } \\
\text { cost }\end{array}$ & $\begin{array}{c}\text { Environmental } \\
\text { cost }\end{array}$ & Total cost & $\begin{array}{c}\text { Financial } \\
\text { cost }\end{array}$ & $\begin{array}{l}\text { Environmental } \\
\text { cost }\end{array}$ & Total cost \\
\hline Pile foundation & PF1 & PF1 & PF1 & - & - & - \\
\hline Outer wall & OW1 & & & OW4 & OW3 & OW1 \\
\hline Flat roof & FR1 & & & FR1 & FR2 & \\
\hline Floor on grade & FG1 & & & FG1 & & \\
\hline $\begin{array}{l}\text { Loadbearing } \\
\text { inner wall }\end{array}$ & LIW2 & LIW1 & LIW2 & - & & \\
\hline $\begin{array}{l}\text { Non-bearing } \\
\text { inner wall }\end{array}$ & NIW1 & NIW2 & NIW1 & NIW1 & NIW2 & \\
\hline Glazing & DG & TIG & & DG & TIG & \\
\hline
\end{tabular}

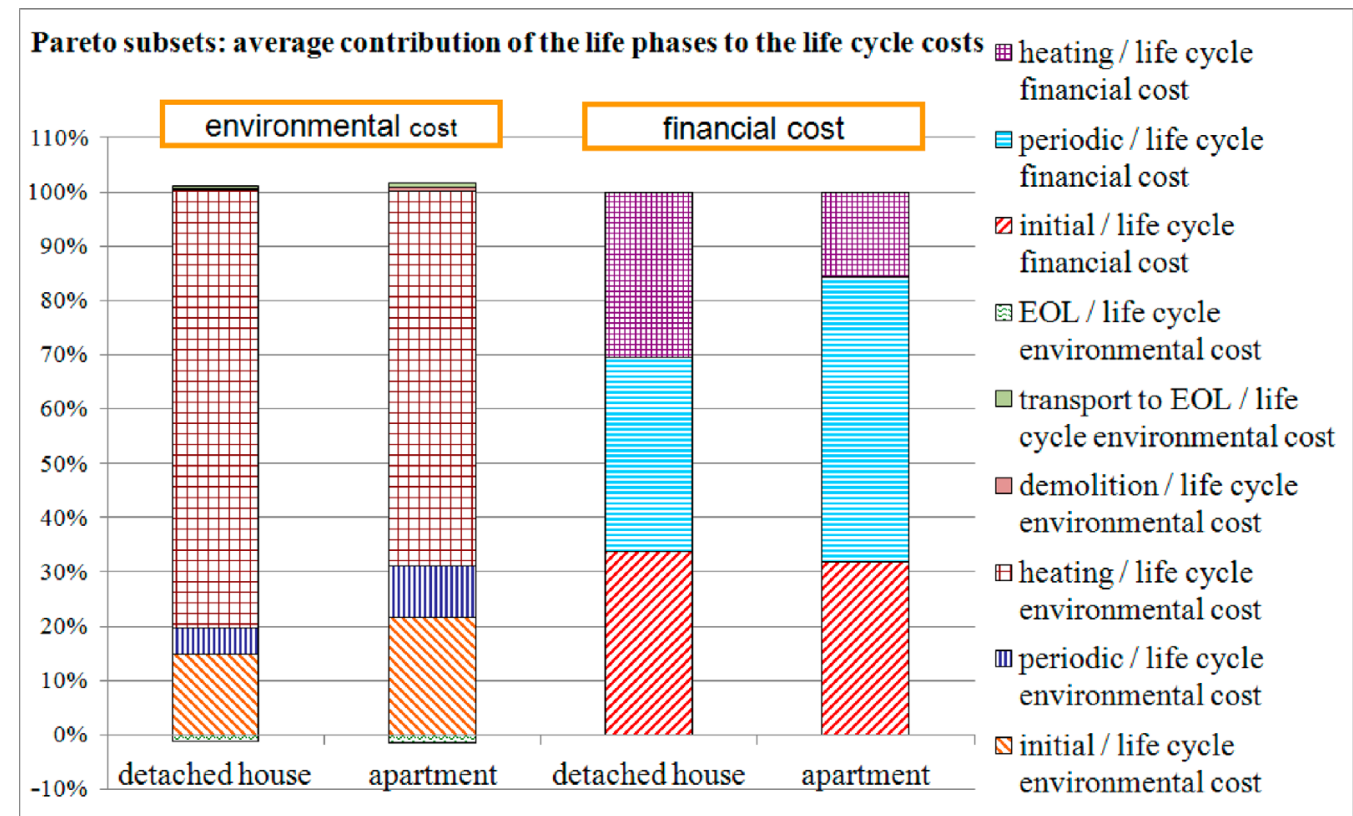

Figure 8: Detailed analysis of the contribution of the phases to the life cycle financial and environmental cost for both dwelling types.

A comparison of the two dwellings revealed that the heating cost is more important for the detached house than for the apartment, as could be expected because it is less compact. The periodic costs for cleaning, maintenance and replacements on the other hand are higher on average for the apartment. This can be explained by the spaces shared between the apartments, induce financial costs in the first place due to the labour activities (cleaning). 


\subsection{Importance of the different building elements}

Although the analysis clarified that on average the initial phase is responsible for only $20 \%$ of the life cycle environmental cost and $33 \%$ of the life cycle financial cost, this phase is suspected to contribute to more costs for better insulated dwellings. Especially in the case of low energy and passive houses, this phase will presumably become significantly more important. Therefore, the contribution of the different elements to the initial environmental and financial costs was investigated in order to determine which elements should be focused on first (Fig. 9).

Large differences are apparent between the two dwelling types. The elements that contribute most to the initial environmental cost in the detached house are the flat roof and the floor on grade, followed by the outer walls, while the intermediate floors contribute most to the initial environmental cost of the apartment.

For the financial cost, the same trends were noted, although some small shifts appeared. For the detached house, the outer walls contribute more to the initial financial cost than the floor on grade, while the contribution of the foundation is reduced compared with its contribution to the environmental cost. For the apartment the intermediate floors are still the most important contributors to the initial financial cost, but this is again reduced compared with the environmental cost.

\subsection{Importance of the choice of functional unit}

Since the choice to express the costs per $\mathrm{m}^{2}$ floor can be questioned (larger dwellings lead to a lower cost per $\mathrm{m}^{2}$ floor), the costs were also investigated 'per dwelling' and 'per inhabitant'. The results are shown in the graphs in Fig. 10. This comparison revealed that the conclusions based on the analysis per $\mathrm{m}^{2}$ floor do not alter for the other functional units. However, the difference between the two dwellings is slightly changed in favour of the apartment.

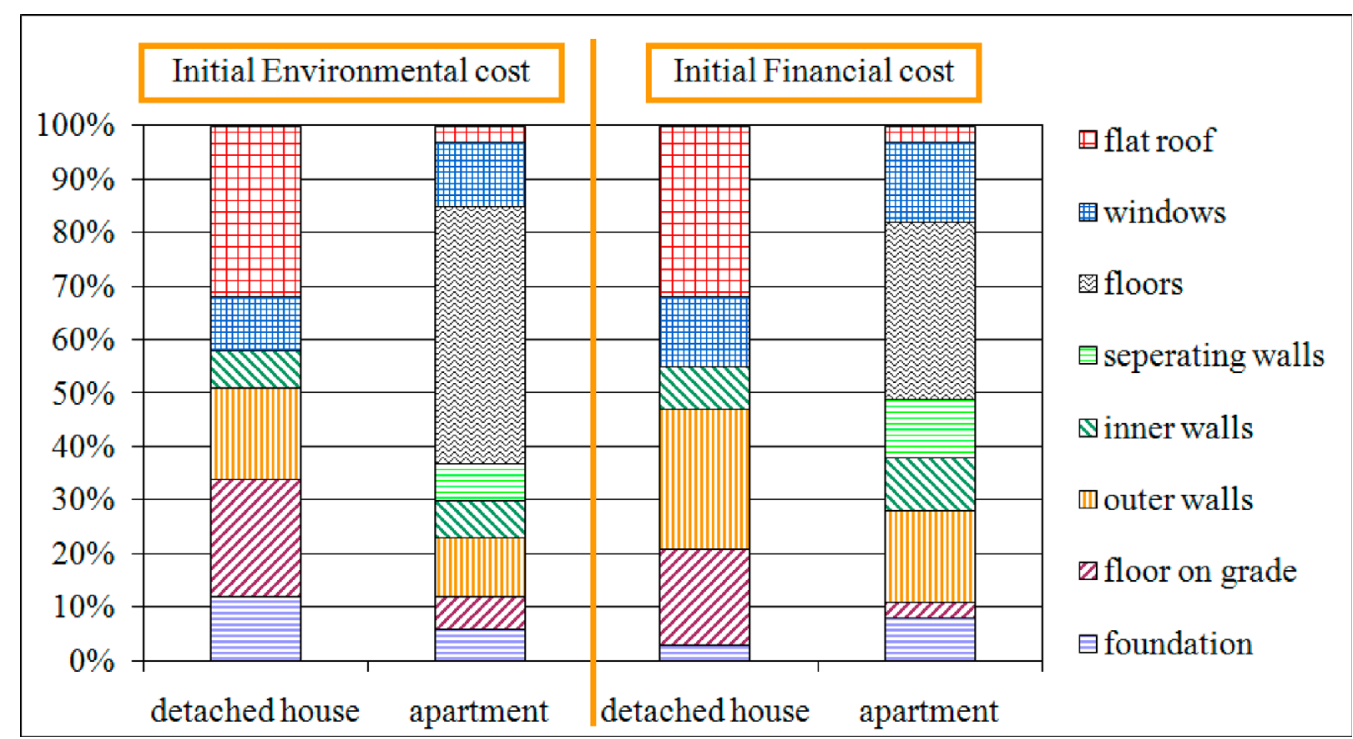

Figure 9: Average contribution of the different building elements to the environmental and financial investment cost of the building. 
life cycle environmental cost
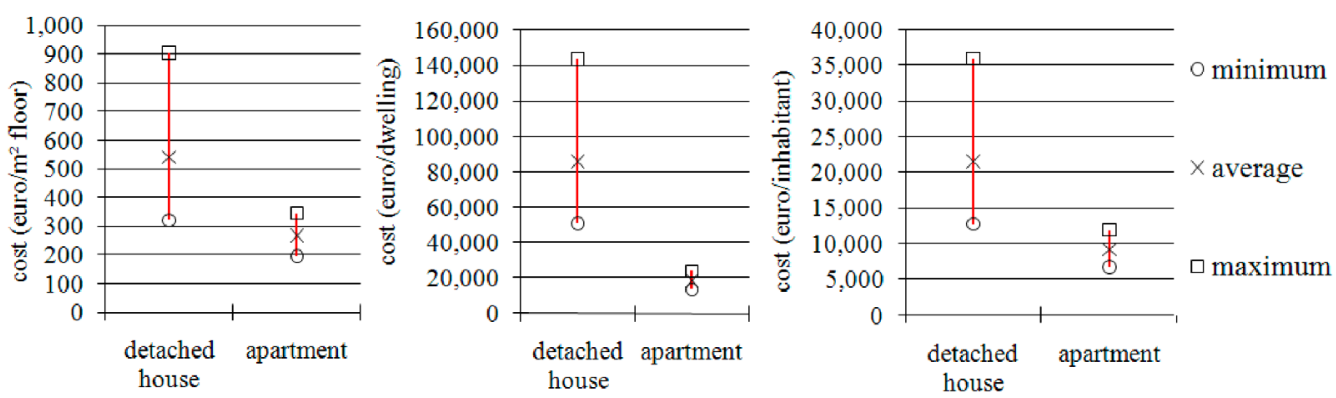

Figure 10: Analysis of the minimum, maximum and average life cycle environmental cost for both dwelling types, expressed 'per $\mathrm{m}^{2}$ floor', 'per dwelling' and 'per inhabitant'.

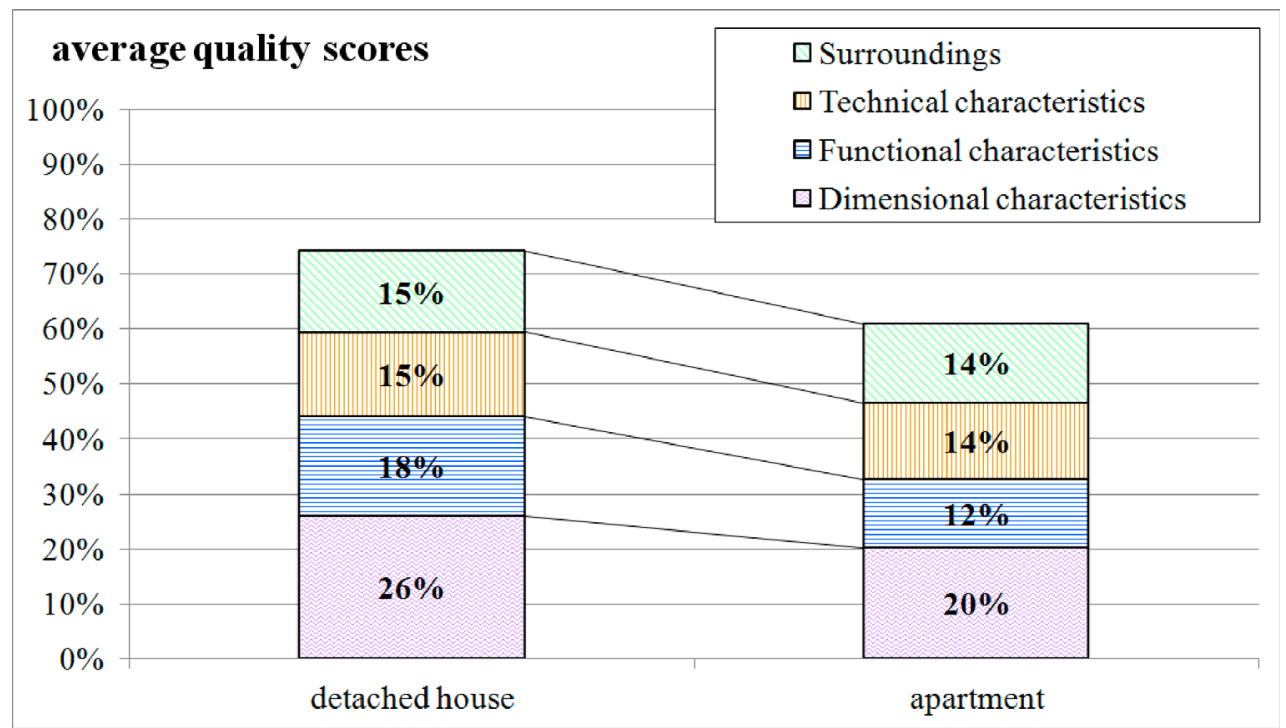

Figure 11: Average quality score of the analysed detached house and apartment.

The analysis confirmed the earlier conclusion that the optimisation opportunities are more extended for the detached house than for the apartment: there is obviously a larger difference between its minimum and maximum life cycle environmental cost.

\subsection{Cost/quality optimisation}

For the cost/quality optimisation, the alternative that offered the highest quality increase for the lowest additional cost was identified according to the same procedure used in the cost optimisation. The analysis revealed that the quality is identical for many options. This can be explained by the fact that all of the chosen technical solutions fulfil the European and Belgian performance norms and standards, resulting in little quality differences. However, the quality evaluation was important when optimising the layout of the dwelling [5]. 
The comparison of the average quality of the detached house and the apartment revealed that the quality of the detached house is higher. This means that, although the costs are higher for this dwelling type, people may prefer it because of its quality. The subsets of Pareto optima based on cost/ quality proved to be different from the subsets based on costs only. One remarkable difference is the preference for ceramic tiles as floor finishing when considering the quality (ease of maintenance), while carpet is preferred when only costs are considered.

\section{CONCLUSION}

The proposed methodology to optimise the sustainability of the Belgian dwelling stock considered financial and environmental costs based on life cycle analysis and also included a quality evaluation. The Pareto approach was used to define the optimal solutions. The implementation of the methodology to a detached house and an apartment revealed that it is feasible to obtain a large reduction in the life cycle environmental cost - for an assumed life span of 60 years - for only a minor extra financial investment.

Furthermore, the analysis showed that the optimisation criterion (financial cost, environmental cost or total cost) is a determining factor. For example, from an environmental point of view calcium silicate blocks are preferred for the inner walls while clay building blocks are financially preferred.

For the case studies, internalisation of the environmental cost led to an $8 \%$ increase in investment cost on average while the maintenance cost (including cleaning and replacements) increased by $2 \%$ and the heating cost by $55 \%$. While the life cycle environmental cost was mainly determined by the heating cost, the initial and periodic costs for cleaning, maintenance and replacements contributed most to the life cycle financial cost.

The contribution of the building elements to the initial financial and the initial environmental cost differed for the two analysed dwelling types. Therefore, depending on the dwelling type, other elements should be focused on during optimisation.

Although the environmental and/or financial cost was higher for a certain option, one may chose for it because of its better quality. This was clearly shown by the optimisation procedure including quality aspects.

In the second phase of this research, the methodology is being refined and implemented to define actions in order of priority for improvements of different dwelling types and to compare these mutually. Based on the results, policy recommendations will be formulated.

\section{ACKNOWLEDGEMENT}

We extend our sincere thanks to BELSPO - SSD (Belgian Science Policy - Science for a Sustainable Development) who have funded this research and to the collaborating research partners, VITO and BBRI.

\section{REFERENCES}

[1] FOD economie, K.M.O., Middenstand en Energie. (2009). Statistical data Belgium, from www.statbel.fgov.be/figures/download_nl.asp\#6 (accessed July 2009)

[2] Eurima (2010). Eurima Insulation thickness survey 2004, from www.eurima.org/insulationthickness/(accessed September 2010)

[3] Dijkmans, R., A transparent and proven methodology for selection of Best Available Techniques (BAT) at the sector level by Guided expert judgment. Journal of Cleaner Production, 1, pp. 11-21, 2000. doi: http://dx.doi.org/10.1016/S0959-6526(99)00308-X

[4] a.a. Besluit van de Vlaamse Regering van 11 maart 2005 tot vaststelling van de eisen op het vlak van de energieprestaties en het binnenklimaat van gebouwen. Brussels, Belgium: Belgisch Staatsblad, 2005a. 
[5] Allacker, K., De Troyer, F., Spirinckx, C., De Nocker, L., Vercalsteren, A., Tomasetig, B. \& Putzeys K. Striving for a more sustainable Belgian dwelling stock. Proceedings of the fifth International Conference on Urban regeneration and Sustainability - The Sustainable City V. WITPress: Southamption, Boston, pp. 335-344, 2008.

[6] Barrow, C. Environmental and Social Impact Assessment: An Introduction. Arnold, Hodder Headline, PLC: London, UK, 1997.

[7] Waage, S., Geiser, K., Irwin, F., Weissman, A., Bertolucci, M., Fisk, P., Basile, G., Cowan, S., Cauley, H. \& McPherson, A. Fitting together the building blocks for sustainability a revised model for integrating ecological, social and financial factors into business decision-making. Journal of Cleaner Production, 13, pp. 1145-1163, 2005. doi: http://dx.doi.org/10.1016/j. jclepro.2004.06.003

[8] Nijkamp, P. The role of evaluation in supporting a Human Sustainable Development: A cosmonomic perspective. Sustainable Urban Development - Volume 2: The environmental assessment methods, M. Deakin, G. Mitchell, P. Nijkamp \& R. Vreeker, Routledge: Oxon, UK, pp. 94-109, 2007.

[9] Oberg, M. Integrated Life Cycle Design - Applied to Swedish concrete multi-dwelling buildings. Doctoral dissertation, Lund Institute of Technology, Lund, Sweden, pp. 9, 2005.

[10] ISO 14040. Environmental management - Life cycle assessment - Principles and framework. ISO, pp. 2, 2006.

[11] Guinée, J., Gorrée, M., Heijungs, R., Huppes, G., Kleijn, R., de Koning, A., van Oers, L., Wegener Sleeswijk, A., Suh, S., Udo de Haes, H.A., de Bruijn, H., van Duin, R. \& Huijbregts M.A.J. Handbook on Life Cycle Assessment: Operational Guide to the ISO Standards. Kluwer Academic Publishers: Dordrecht, The Netherlands, 2002.

[12] IEA. International Energy Agency, Annex 31 Energy-Related Environmental Impact of Buildings - Assessing buildings for adaptability, Canada Mortgage and Housing Corporation: Canada, 2004a.

[13] IEA. International Energy Agency, Annex 31 Energy-Related Environmental Impact of Buildings - Context and Methods for Tool Designers, Canada Mortgage and Housing Corporation: Canada, 2004b.

[14] IEA. International Energy Agency, Annex 31 Energy-Related Environmental Impact of Buildings - Data needs and sources, Canada Mortgage and Housing Coporation: Canada: 2004c.

[15] IEA. International Energy Agency, Annex 31 Energy-Related Environmental Impact of Buildings - Environmental framework, Canada Mortgage and Housing Corporation: Canada 2004d.

[16] IEA. International Energy Agency, Annex 31 Energy-Related Environmental Impact of Buildings - Life Cycle Assessment Methods for Buildings, Canada Mortgage and Housing Corporation: Canada, 2004e.

[17] IEA. International Energy Agency, Annex 31 Energy-Related Environmental Impact of Buildings - Types of tools, Canada Mortgage and Housing Corporation: Canada, 2004f.

[18] SETAC. A Technical Framework for Life-Cycle Assessment, SETAC Foundation: Pensacola, US, 1991.

[19] ISO 14044. Environmental Management - Life Cycle Assessment-Requirements and Guidelines. ISO, 2006.

[20] SETAC. Life-Cycle Assessment in Building and Construction: A State-of-the-Art Report. Society of Environmental Toxicology and Chemistry, SETAC Press: North Carolina, USA, 2003.

[21] REGENER. European methodology for the evaluation of Environmental impact of buildings Life Cycle Assessment - application of the life cycle analysis to buildings, Detailed description and review, Final report of EU REGENER project. REGENER, 1997. 
[22] ISO 15686-1. Buildings and Constructed Assets - Life Cycle Assessment - Requirements and Guidelines, ISO: Paris, France, 2006.

[23] Ammar, C. \& Longuet, M., Belgian Requirements About Buildings Service Life. Durability of Building Materials and Components, pp. 77-90, 1980. doi: http://dx.doi.org/10.1520/ STP36050S

[24] BBRI. Guide pratique pour l'Entretien des Bâtiments: BBRI: Belgium, 1991.

[25] SBR. Levensduur van bouwproducten.: Stichting BouwResearch (SBR): Rotterdam, The Netherlands, 1998.

[26] NIBE. Classification, Basiswerk duurzaam en gezond bouwen. De leidraad bij het realiseren van duurzame en gezonde woning-en utiliteitsbouw: Nibe Publishing bv: Bussum, The Netherlands, 2003.

[27] INIES. INventaire des Impacts Environnementaux et Sanitaires, France, from www.inies.fr (accessed March 2011), 2007.

[28] Seongwon, S. International review of environmental assessment tools and databases - report 2001-006-B-02: CRC for Construction Innovation, 2002.

[29] BRE. BREEAM: The Environmental Assessment Method for Buildings Around The World, from www.breeam.org/(accessed February 2011), 2011

[30] Peuportier, B. \& Putzeys, K., PRESCO, WP2 Inter-Comparison and Benchmarking of LCABased Environmental Assessment and Design Tools - final report. PRESCO, 2005.

[31] Verbeeck, G., Optimisation of Extremely Low Energy Residential Buildings. Doctoral dissertation, Katholieke Universiteit Leuven, Leuven, Belgium, 2007.

[32] a.a. Besluit van de Vlaamse Regering van 11 maart 2005 tot vaststelling van de eisen op het vlak van de energieprestaties en het binnenklimaat van gebouwen - bijlage I. Brussels, Belgisch Staatsblad: Belgium, 2005b.

[33] VEA (2009). Vlaams Energieagentschap - energiesparen, from: www.energiesparen.be (accessed November 2009)

[34] a.a. Guide Pratique pour l'Entretien des Bâtiments. le Conseil National de l'Ordre des Architects, le Colléges des Experts Architectes de Belgique, la Confédération Nationale de la Construction (C.N.C.), la Fédération Royale des Sociétés d'Architects de Belgique (F.A.B.), SECO and CSTC, 1991a.

[35] Perret, J. Guide de la maintenance des bâtiments, Diagnostic d'un patrimoine bâti existant, prévention des désordres et actions pour y remédier, 308 fiches tecniques de suivi des ouvrages. Paris, France: Le Moniteur, 1995.

[36] De Troyer, F. Bouweconomie en Systeembouw, ACCO: Leuven, Belgium, 2007.

[37] a.a. Cost Control in Building Design. Her Majesty's stationery office: London, UK, 1968.

[38] ecoinvent. Swiss Centre for Life Cycle Inventories, from www.ecoinvent.org (accessed December 2010), 2009

[39] Goedkoop, M. \& Spriensma, R. The Eco-Indicator 99 A damage oriented method for Life Cycle Impact Assessment - Methodology Report, Pré Consultants B.V: Amersfoort, The Netherlands, 2001

[40] Tol, R.S. The marginal damage costs of carbon dioxide emissions: an assessment of the uncertainties. Energy Policy, 33, pp. 2064-2074, 2005. doi: http://dx.doi.org/10.1016/j.enpol.2004.04.002

[41] Stern, N. Stern Review: The Economics of Climate Change, Cambridge University Press: Cambridge, UK, 2006.

[42] Watkiss P., Downing, T.E., Anthoff, D., Butterfield, R., Ceronsky, M., Grubb, M., Guo, J., Hepburn, C., Hope, C., Hunt, A., Li, A., Markandya, A. Moss, S., Nyong, A. \& Tol, R.S.J. Scoping 
Uncertainty in the Social Cost of Carbon. Final Project Report, Social Cost of Carbon: A Closer look at Uncertainty, Department of Environment, Food and Rural Affairs: London, UK, 2005.

[43] Holland, M., Pye, S., Watkiss, P., Droste-Franke, B. \& Bickel, P. Damages per tonne emission of PM2.5, $\mathrm{NH}_{3}, \mathrm{SO}_{2}, \mathrm{NOx}$ and VOCs from each EU25 Member State (excluding Cyprus) and surrounding seas, AEA Technology Environment: Didcon, Oxon, UK, pp. 14-18, 2005.

[44] Allacker, K. Sustainable Building: The Development of an Evaluation Method. Doctoral dissertation, Katholieke Universiteit Leuven, Leuven, Belgium, 2010.

[45] ASPEN. ASPENINDEX - Nieuwbouw, edition 39. Antwerp, Belgium: ASPEN, 2006a.

[46] Pasman, W., Scholten, J.G. \& Veldkamp, I. Burgerwerk en kleine aannemingen - onderhoud en herstel, Misset Bouw: Doetinchem, The Netherlands, 1/1993.

[47] Hollander den, T., Kuhlmann, W., Steenhuis, J. \& Veldkamp, I., Woningbouwkosten - Groot onderhoud en renovatie, Misset bouw: Doetinchem, The Netherland, 3/1993.

[48] Ten Hagen Stam. Bouwkosten - Burgerwerk - Groot Onderhoud - update, Ten Hagen \& Stam: Den Haag, The Netherlands, 2000a.

[49] Ten Hagen Stam. Bouwkosten - Burgerwerk - Klein Onderhoud - update, Ten Hagen \& Stam: Den Haag, The Netherlands, 2000b.

[50] Ten Hagen Stam. Herstelkosten bouwgebreken 1999, Ten Hagen \& Stam: Den Haag, The Netherlands, 2000c.

[51] ASPEN. ASPENINDEX - Onderhoud, ombouw, edition 39. ASPEN: Antwerp, Belgium, 2006 b.

[52] European Commission. Eurostat - European statistics, from Eurostat:nui.epp.eurostat.ec. europa.eu/nui/setupModifyTableLayout.do (accessed October 2009), 2009.

[53] Dexia Bank. De spaarrekening: interessant als belegging?. Nieuwsbrief van Dexia Bank, January 2007: 1, 2007.

[54] ABEX. Associatie van Belgische Experten, from: www.abex.be. (accessed June 2009), 2009.

[55] Federaal Planbureau. Economische vooruitzichten 2007-2012. Federaal Planbureau, communiqué dd. 11 May 2007, from: www.plan.fgov.be. (accessed June 2007), 2007.

[56] D'haeseleer W., et al. Belgium's Energy Challenges Towards 2030. Commission Energy 2030, Brussels, from: www.ce2030.be. (accessed June 2007), 2007.

[57] Weitzman, M. Just keeping discounting, but. Discounting and Intergenerational Equity, F. Weynant: Resources for the future: Washington, US, 1999.

[58] a.a. Method for the evaluation of the quality of dwellings in the design phase (translated title) Methode voor de beoordeling van de kwaliteit van woningen in de ontwerpfase. Brussels, Belgium: Ministerie van de Vlaamse Gemeenschap - bestuur Huisvesting, $1991 \mathrm{~b}$.

[59] Vreeker, R., Nijkamp, P. \& Munda, G. Evaluation of sustainable urban development: Costbenefit analysis and multicriteria analysis. Sustainable Urban Development - Volume 2: The environmental assessment methods, M. Deakin, G. Mitchell, P. Nijkamp, \& R. Vreeker, Routledge: Oxon, UK, 141-157, 2007.

[60] Lombardi, P. The Analytic Hierarchy Process. Sustainable Urban Development - Volume 2: The environmental assessment methods. M. Deakin, G. Mitchell, N.P., \& R. Vreeker, Routledge: Oxon, UK, pp. 209-222. 2007.

[61] Baycan-Levent, T., Bruinsma, F. \& Nijkamp, P. Urban spiders: A comparative framework for evaluation and scenario analysis. Sustainable Urban Development - Volume 2: The environmental assessment methods, M. Deakin, G. Mitchell, P. Nijkamp \& R. Vreeker, Routledge: Oxon, UK, pp. 236-253, 2007.

[62] Allacker, K. \& De Troyer, F. Integrated sustainability assessment of dwellings in the Belgian context. Proceedings of the 3rd CIB International Conference on Smart and Sustainable Built Environments (SASBE09). SASBE: Delft, The Netherlands, ISBN 97890 5269373, 2009. 